\title{
Maternal recognition of pregnancy in the horse
}

\author{
Terttu Katila \\ University of Helsinki, Faculty of Veterinary Medicine, Department of Production Animal Medicine, Saarentaus, Finland
}

\begin{abstract}
Summary
Maternal recognition of pregnancy (MRP) in the horse is completed around days 14 to 15 after ovulation, but events leading to it probably begin already at about day 10. Release of prostaglandin F2 $\alpha$ (PGF2 $\alpha$ ) from the endometrium, and thus, luteolysis has to be prevented to maintain high progesterone levels and pregnancy. At the time of expected luteolysis, PGF2 $\alpha$ concentrations are lowered in the uterine vein and lumen in pregnant as compared to non-pregnant mares. This is associated with downregulation of endometrial oxytocin (OT) receptors and cyclooxygenase enzyme (COX-2) expression. Both the conceptus and the endometrium produce estrogens, PGE2, PGF2 $\alpha$, and OT; their major role seems to be the induction of myometrial contractions and embryo mobility. Because the early equine conceptus is small and spherical, mobility is thought to be important in spreading the message about embryo presence to the entire uterus. The nature of this message is not known; it has also been suggested that mere physical contact of the embryo with the endometrial wall could play a role in MRP. Local stimulation of uterine blood flow by the conceptus has been demonstrated, which could be caused by estrogen production and/or by physical contact. Progesterone and estrogen are necessary for the production of uterine-specific proteins for the developing embryo. Many genes are up- or down-regulated during and after MRP, but their roles remain to be elucidated.
\end{abstract}

Keywords: horse, pregnancy, prostaglandin, oxytocin, estrogen, progesterone, endometrium, corpus luteum, conceptus, blood flow, reproduction

\begin{abstract}
Maternale Erkennung der Gravidität beim Pferd
Die maternale Erkennung der Gravidität (MRP) beginnt etwa 14-15 Tage nach der Ovulation, doch diesbezügliche Veränderungen beginnen wahrscheinlich bereits um den 10. Tag. Die Freisetzung von Prostaglandin F2 $\alpha$ durch das Endometrium erfolgt nicht und somit wird die Luteolyse verhindert. Bei tragenden Stuten sind zum Zeitpunkt der erwarteten Luteolyse im Vergleich zu nicht-tragenden Stuten die PGF2 $\alpha$ Konzentrationen in der uterinen Vene und im Lumen niedriger. Dies ist assoziiert mit einer 'Downregulation ` der endometrialen OxytocinRezeptoren und der Expression von Rezeptoren der Cyclooxygenase-Enzyme (COX-2). Sowohl der Embryo als auch das Endometrium synthetisieren Östrogen, PGE2, PGF2 $\alpha$ und Oxytocin; ihre Hauptfunktion scheint die Induktion myometrialer Kontraktionen und der embryonalen Mobilität zu sein. Da der junge Embryo beim Pferd klein und kugelförmig ist, wird angenommen, dass um die Präsenz des Embryos im gesamten Uterus zu präsentieren seine Mobilität von besonderer Bedeutung ist. Der genaue Mechanismus des MRP-Signals ist nicht bekannt; es wird unter anderem vermutet, dass allein der physische Kontakt zwischen Embryo und Endometrium für die Erkennung der Gravidität verantwortlich ist. Es konnte demonstrient werden, dass durch den Embryo eine lokale Stimulierung des uterinen Blutflusses hervorgerufen wird, dies könnte auf der embryonalen Östrogensynthese und/oder dem physischen Kontakt beruhen. Progesteron und Östrogen sind für die Synthese von spezifischen Uterusproteinen, welche für die Entwicklung des Embryos benötigt werden notwendig. Viele Gene werden 'up- oder down' -reguliert während und nach der MRP, allerdings ist deren Bedeutung hinsichtlich der MRP noch zu klären.
\end{abstract}

Schlüsselwörter: Pferd, Gravidität, Prostaglandin, Oxyłocin, Östrogen, Progesteron, Endometrium, Corpus luteum, Embryo, Blutfluss, Reproduktion

In a cyclic non-pregnant mare the corpus luteum $(\mathrm{CL})$ is destroyed by prostaglandin F2 $\alpha$ (PGF2 $\alpha$ ) at about day 14 of the cycle (Neely et al. 1979). In a pregnant mare, the CL has to continue its life-span and progesterone production in order to stimulate the endometrium to produce appropriate histotrophe for the nourishment of the developing embryo. The presence of the embryo is somehow signaled to the endometrium and as a consequence luteolysis does not take place (Hershman and Douglas 1979). This event is called maternal recognition of pregnancy (MRP).

In the horse, pregnancy is recognized first when the embryo travels through the oviduct. Unfertilized oocytes are retained in the oviduct (Van Niekerk and Gerneke 1966), while the embryo descends into the uterus. However, this does not prevent luteolysis subsequently, and other mechanisms are needed to inhibit prostaglandin release and the resultant luteolysis. The endometrium plays a major role in this process. MRP has been studied in mares for decades, but still we don't know all the details and sequences in the process of MRP.

\section{Prostaglandin F2}

Prostaglandin F2 $\alpha$ is the natural luteolysin in farm animals and also in horses (McCracken et al. 1999). During MRP, it is critical that the action of PGF2 $\alpha$ on the $\mathrm{CL}$, i.e. luteolysis is prevented. In farm animals, the conceptus accomplishes this by reducing the secretion of PGF $2 \alpha$, or altering the direction of PGF2 $\alpha$ secretion so that it does not reach the $\mathrm{CL}$ (swine) (Bazer and Thatcher 1977), or by secreting an antiluteolytic substance (ruminants), which alters the pattern of PGF2 $\alpha$ secretion so that no pulses are generated (Spencer and Bazer 1996).

Evidently, the mare utilizes either a luteostatic or anti-luteolytic mechanism to prevent PGF2 $\alpha$ secretion/release. The concentration of the PGF2 $\alpha$ metabolite, 13,14-dihydro-15-PGF (PGFM) in peripheral circulation is lower in pregnant than in non-pregnant mares around the time of MRP (Kindahl et al. 1982). At the time of expected luteolysis, PGF2 $\alpha$ concentrations are lower in the uterine vein and uterine lumen of preg- 
nant compared to non-pregnant mares (Douglas and Ginther 1976, Zavy et al. 1978). This shows that redirection of PGF2 $\alpha$ into the uterine lumen to prevent it reaching the $\mathrm{CL}$, like in the sow, does not happen in the mare. Another mechanism to prevent the luteolytic action of PGF $2 \alpha$ on $\mathrm{CL}$ could be reduced binding to its receptor, but it has been shown that binding is similar in corpora lutea obtained from pregnant and non-pregnant mares (Vernon et al. 1979). Many studies have been conducted to detect possible luteotropic substances secreted by the embryo, but so far to little avail.

Phospholipase A2 cleaves arachidonic acid from intracellular phospholipid stores. Catalyzed by cyclooxygenase (COX) enzymes, free arachidonic acid is oxidized to prostaglandins and thromboxanes. Of the two isoforms, COX-1 and COX-2, COX-2 expression is changed during equine pregnancy. In endometrial biopsies of mares, COX-2 expression was significantly increased on day 15 of the estrous cycle, but not on day 15 of pregnancy. Furthermore, the presence of conceptus blocked COX-2 expression on day 15 suggesting that it serves as a mechanism to suppress uterine PGF2 $\alpha$ release and to prevent luteolysis (Boerboom et al. 2004). This finding is supported by Eroh and Ealy (2007) who showed 28-fold higher COX-2 mRNA expression in the endometrium of nonpregnant mares on day 14 as compared to pregnant mares. Interestingly, inert intrauterine plastic spheres known to prevent luteolysis reduced (2/5 mares) or inhibited (3/5 mares) COX-2 expression (Rivera del Alamo et al. 2010). Thus, COX-2 is upregulated at the time of luteolysis and downregulated during luteostasis and early pregnancy. It has been suggested that the conceptus induces the endometrium to produce an inhibitor of PGF2 $\alpha$, which blocks the conversion of arachidonic acid to PGF2 $\alpha$ (McDowell and Sharp 2011).

Although PGF2 $\alpha$ concentrations are reduced in the uterine lumen of pregnant mares, the endometrium of pregnant mares and the conceptus produce PGF2 $\alpha$ (Vernon et al. 1981, Stout and Allen 2002). It is likely that PGF2 $\alpha$ produced by the conceptus does not enter the systemic circulation but remains within the uterine lumen where it acts locally stimulating the uterine contractions necessary for embryo mobility. On the other hand, cytosol prepared from pregnant endometrium (Watson 1991), day 9 to 16 conceptuses (Sissener et al. 1996), and co-incubation of endometrial explants with conceptus membranes (Sharp et al. 1984) suppressed PGF $2 \alpha$ in vitro. Later, on days 18 and 20 of pregnancy, PGF2 $\alpha$ concentrations in uterine flushings were similar to in non-pregnant mares on day 14.

It has been suggested that after day 18 the horse has to have some other mechanisms to prevent luteolysis (Stout and Allen 2002). In addition, it appears that mares have a biological clock where ovulation initiates a cascade of processes as a result of the change from low progesterone (estrus) to increasing progesterone (after ovulation). If there is no preceding low progesterone, luteolysis cannot be timed to take place 14 days later (Hofferer et al. 1991). This results in prolonged luteal function, usually for 2 months (1-3 months), no matter what the reason for the initial failure to return to estrus is (Stabenfeldt et al. 1974). In pregnant mares, equine Chorionic Gonadotropin (eCG) produced by endometrial cups starting 36-40 days after ovulation induces accessory corpora lutea and has luteotropic effects preventing luteolysis. After 60 to
90 days, the placenta takes over the progesterone production and CLs are no longer necessary (Ginther 1992). Therefore, it is possible that the initial prevention of luteolysis by the conceptus on day 14 is all that is needed to maintain high progesterone levels for long enough to ensure pregnancy maintenance.

\section{Prostaglandin E2}

Both the conceptus and the endometrium synthesize PGE2 (Stout and Allen 2002, Boerboom et al. 2004). The endometrial PGE2:PGF2 $\alpha$ production ratio is increased in pigs by estrogen, which originates from the conceptus (Ziecik 2002). PGE2 production by the equine conceptus in vitro was high until day 32 of pregnancy (Stout and Allen 2002), but microsomal PGE2 synthase expression in endometrial biopsies at days 14-16 did not differ between pregnant and non-pregnant mares (Boerboom et al. 2004). PGE2 is thought to be antiluteolytic in other species, but in mares PGE2 does not seem to be luteotropic. The large amounts of PGE2 produced by the conceptus probably stimulate myometrial contractions between days 10 and 16 (Allen 2001).

\section{Oxytocin}

In the mare, oxytocin (OT) is secreted by the hypothalamus, endometrium, and CL (Stevenson et al. 1991, Behrendt et al. 1997). PGF2 $\alpha$ pulses stimulate OT release from the pituitary (Vanderwall et al. 1998). In the non-pregnant mare, exogenous OT causes PGF $2 \alpha$ release and exogenous PGF2 $\alpha$ causes OT release. This positive feedback is disrupted during pregnancy (McDowell and Sharp 2011).

Although OT stimulates PGF2 $\alpha$ production, once or twice daily injections of OT from day 8 or 9 to day 14, or subcutaneous osmotic minipumps releasing continuously small amounts of OT prevented luteolysis in non-pregnant mares, suggesting a role for OT receptors in MRP (Goff et al. 1987, Stout et al. 1999, Vanderwall et al. 2007). Endometrial OT receptor concentrations are low during estrus and increase during diestrus, but more so between days 12 and 14. This increase does not take place in pregnant mares (Sharp et al. 1997, Starbuck et al. 1998).

It seems that upregulation of OT receptors has to be inhibited during MRP. One possibility is that the conceptus produces a substance(s) that inhibits OT receptors or interferes with the interaction of OT with its receptor. It has also been suggested that the direction of OT secretion is changed during MRP. Whereas in the non-pregnant mare OT is secreted into the uterine lumen, where it acts in an autocrine manner stimulating PG production, in the pregnant mare the direction could be into the myometrium to stimulate uterine contractions (McDowell and Sharp 2011 ). There is no evidence, however, to support this kind of mechanism in the mare MRP.

\section{Estrogens and proteins}

For a long time, estrogen was proposed as the signal for MRP, since it is the major signal in swine, since the equine concep- 
tus produces estrogens, and since estradiol and estrone concentrations are elevated in the uterine lumen of pregnant mares on days 10 to 20 (Zavy et al. 1984). However, estradiol has been shown to increase PGF2 $\alpha$ production in vitro (Vernon et al. 1981). In addition, systemic administration of estrogen to mares followed by oxytocin increased PGFM levels fivefold compared to controls (Goff et al. 1993). Intrauterine administration of estradiol in mineral oil vehicle on days 8 to 14 of pregnancy did not prevent luteolysis, but estradiol in vegetable oil prevented luteolysis probably because of the inhibitory effect of fatty acids on PG synthesis (Wilsher and Allen 2010).

It is likely that estrogens produced by the conceptus are important in inducing pregnant-specific uterine proteins and in facilitating uterine contractions. The uterus-specific proteins are similar in pregnant and diestrous mares on days 12 and 14 after ovulation, but after that the secretory profile of proteins changes. Although uterine proteins are important for embryonic and placental development, their possible role in MRP is not known (McDowell and Sharp 2011).

Both the embryo and the endometrium produce significant quantities of insulin-like growth factor (IGF-1) which is independent of estrogen secretion (Walters et al. 2001). This growth factor certainly has a role in autocrine-paracrine maternal-conceptus signaling but it is probably not an MRP signal.

Changes in gene expression around MRP are poorly understood, but research in this area is now active because the equine genome is known and published. Many genes are upregulated or downregulated between days 12 and 15 in embryos and in the endometrium, e.g. alpha-fetoprotein and pregnancy-associated glycoprotein are upregulated (McDowell and Sharp 2011).

\section{Embryo mobility}

Unlike in many other farm animals, the equine conceptus remains spherical and small in diameter. Therefore, it would be very difficult for the conceptus to spread its MRP signal to the whole uterus. The problem has been solved by continuous and lively mobility of the embryo from day 11 until day 15-16 of pregnancy (Ginther 1983). Mobility is detected already on days 9 and 10, but maximum mobility is seen between days 11 to 14 (Leith and Ginther 1984). With the help of mobility, the embryo can signal its presence, and even small amounts of any substance can be effectively spread over the entire uterus to prevent PGF $2 \alpha$ release. This was confirmed in experiments where the mobility of the conceptus was prevented by placing a restricting ligature around the base of a uterine horn (McDowell et al. 1985 and 1988). When about $50 \%$ of the uterus was available for the embryo, $50 \%$ of the mares lost the pregnancy; when only the uterine horn ipsilateral to the side of ovulation was accessible, $12 \%$ of the mares maintained the pregnancy. Administration of synthetic progestin to the mares with ligated uterus resulted in 4/5 mares carrying the pregnancy (McDowell et al. 1988). Unrestricted mobility may be critical not only for luteostasis, but also for the maximal access to histotroph.
Uterine contractions are needed for embryo migration, and it has been shown that uterine contractions are stronger and more frequent in early pregnant mares as compared to nonpregnant mares (Cross and Ginther 1988, Griffin and Ginther 1990). Embryo mobility was markedly reduced when flunixin meglumine, a PG inhibitor, was administered to pregnant mares on days 10 to 14 after ovulation (Stout and Allen 2001), and location changes of the embryo occurred less frequently in clenbuterol treated mares (Leith and Ginther 1985). Both studies indicate involvement of uterine contractions in embryo mobility. Fluid-filled plastic balls also move in the uterus but not as readily and frequently as embryos (Ginther 1985, Rivera del Alamo et al. 2008). These studies show that the embryo, and particularly the hormones that it secretes, also plays a role in the mobility. Estrogen, OT, PGF2 $\alpha$, and PGE2 are all important in inducing myometrial contractions, and subsequently embryo mobility (Allen 2001), but they do not seem to be MRP signals as such. Embryo mobility itself is one of the most important factors in MRP of the horse, and there these hormones have a major role.

\section{Physical contact with the endometrium}

Inert intrauterine plastic balls are capable of inducing luteostasis in non-pregnant mares (Rivera del Alamo et al. 2008). They downregulate COX-2 and prevent PGF2 $\alpha$ release (Rivera del Alamo et al. 2008 and 2010). Rivera et al. (2008) proposed that the contact with the endometrial wall will somehow mediate the signal of the presence of the plastic sphere to the endometrium which will then respond in a similar fashion as in MRP. However, the nature of the signal is not known.

The mobility of the embryo could also serve the purpose of increasing physical contact with the endometrium. Blood perfusion is increased in the vicinity of the embryo during the mobility phase (Silva et al. 2005). The mechanism of this local stimulation of vascularity is not known, but vascular stimulants produced by the embryo have been proposed. Estrogen has vasostimulatory properties and also prostaglandins F2 $\alpha$ and E2 can stimulate blood flow (Silva et al. 2005). Similar Doppler studies have not been conducted with intrauterine plastic balls, so it is not known, if the pure physical contact would stimulate endometrial blood flow. It remains to be seen if nitric oxide and/or angiogenic factors have any roles in MRP (Roberto da Costa et al. 2007).

\section{References}

Allen W. R. (2001) Fetomaternal interactions and influences during equine pregnancy. Reproduction 121, 513-527

Bazer F. W. and Thatcher W. W. (1977) Theory of maternal recognition of pregnancy in swine based on estrogen controlled endocrine versus exocrine secretion of prostaglandin F2 $\alpha$ by the uterine endometrium. Prostaglandins 14, 397-400

Behrendt C. Y., Adams M. H., Daniel K. S. and McDowell K. J. (1997) Oxytocin expression by equine endometrium. Biol. Reprod. 56 (Suppl. 1), 134

Boerboom D., Brown K. A., Vaillancourt D., Poitras P., Goff A. K., Watanabe K., Doré M. and Sirois J. (2004) Expression of key prostaglandin synthases in equine endometrium during late diestrus and early pregnancy. Biol. Reprod. 70, 391-399

Cross D. T. and Ginther O. J. (1988) Uterine contractions in nonpregnant and early pregnant mares and jennies as determined by ultrasonography. J. Anim. Sci. 66, 250-254 
Douglas R. H. and Ginther O. J. (1976) Concentration of prostaglandins $F$ in uterine venous plasma of anesthetized mares during the estrous cycle and early pregnancy. Prostaglandins 11, 251-260

Eroh M. L. and Ealy A. D. S. (2007) Pregnancy status and steroid exposure impact the abundance of endometrial cyclooxygenase-2 mRNA in mares. Biol. Reprod. 77, (Suppl. 1), 113

Ginther O. J. (1983) Mobility of the early equine conceptus. Theriogenology 19,603-611

Ginther O. J. (1985) Dynamic physical interactions between the equine embryo and uterus. Equine Vet. J., Suppl. 3, 41-47.

Ginther O. J. (1992) Reproductive biology of the mare. Basic and applied aspects. Equiservices, USA. 2nd edition, $642 \mathrm{p}$

Goff A. K., Pontbriand D. and Sirois J. (1987) Oxytocin stimulation of plasma 15-keto-13,14-dihydro prostaglandin F-2 $\alpha$ during the oestrous cycle and early pregnancy in the mare. J. Reprod. Fertil., Suppl. 35, 253-260

Goff A. K., Sirois J. and Pontbriand D. (1993) Effect of oestradiol on oxytocin-stimulated prostaglandin F2 alpha release in mares. J. Reprod. Fertil. 98, 107-112

Griffin P. G. and Ginther O. J. (1990) Uterine contractile activity in mares during the estrous cycle and early pregnancy. Theriogenology 34, 47-56

Hershman L. and Douglas R. H. (1979) The critical period for the maternal recognition of pregnancy in pony mares. J. Reprod. Fertil., Suppl. 27, 395-401

Hofferer S., Duchamp G. and Palmer E. (1991) Ovarian response in mares to prolonged treatment with exogenous equine pituitary gonadotrophins. J. Reprod. Fertil., Suppl. 44, 341-349

Kindahl H., Knudsen O., Madej A. and Edqvist L.-E. (1982) Progesterone, prostaglandin F-2 $\alpha$, PMSG and oestrone sulphate during early pregnancy in the mare. J. Reprod. Fertil., Suppl. 32, 353-359

Leith G. S. and Ginther O. J. (1984) Characterization of intrauterine mobility of the early equine conceptus. Theriogenology 22,401 408

Leith G. S. and Ginther O. J. (1985) Motility of the conceptus and uterine contractions in the mare. Theriogenology 24, 701-711

McCracken J. A., Custer E. E. und Lamsa J. C. (1999) Luteolysis: a neuroendocrine-mediated event. Physiol. Rev. 79, 263-323

McDowell K. J., Sharp D. C., Peck Lynn S. and Cheves Laura L. (1985) Effect of restricted conceptus motility on maternal recognition of pregnancy in mares. Equine Vet. J., Suppl. 3, 23-24

McDowell K. J., Sharp D. C., Grubaugh W., Thatcher W. W. and Wilcox C. J. (1988) Restricted conceptus motility results in failure of pregnancy maintenance in mares. Biol. Reprod. 39, 340-348

McDowell K. J. and Sharp D. C. (2011) Maternal recognition of pregnancy. In: Equine Reproduction. McKinnon A. O., Squires E. L., Vaala W. E., Varner D. D. (eds). Wiley-Blackwell, U.K., 2nd ed., 2200-2210

Neely D. P., Kindahl H., Stabenfeldt G. H., Edqvist L.-E. and Hughes J. P. (1979) Prostaglandin release patterns in the mare: physiological, pathophysiological, and therapeutic responses. J. Reprod. Fertil., Suppl. 27, 181-189

Rivera del Alamo M. M., Reilas T., Kindahl H. und Katila T. (2008) Mechanisms behind intrauterine device-induced luteal persistence in mares. Anim. Reprod. Sci. 107, 94-106

Rivera del Alamo M. M., Reilas T., Kindahl H., Rodríguez-Gil J. E., Rigau T. and Katila T. (2010) The luteostatic effect of intrauterine devices in mares is associated with endometrial expression of COX-2. Anim. Reprod. Sci. 121S, S227-228

Roberto da Costa R.P., Ferreira-Dias G., Mateus L., Korzekwa A., Andronowska A., Platek R. and Skarzynski D. J. (2007) Endometrial nitric oxide production and nitric oxide synthases in the equine endometrium: Relationship with microvascular density during the estrous cycle. Dom. Anim. Endocrinol. 32, 287-302

Sharp D. C., Thatcher M. J., Salute M. E. and Fuchs A.-R. (1997) Relationship between endometrial oxytocin receptors and oxytocininduced prostaglandin F2 $\alpha$ release during the estrous cycle and early pregnancy in pony mares. J. Reprod. Fertil. 109, 137-144

Sharp D. C., Zavy M. T., Vernon M. W. and Bazer F. W. (1984) The role of prostaglandins in the maternal recognition of pregnancy in mares. Anim. Reprod. Sci. 7, S269-282
Silva L. A., Gastal E. L., Beg M. A. and Ginther O. J. (2005) Changes in vascular perfusion of the endometrium in association with changes in location of the embryonic vesicle in mares. Biol. Reprod. 72, 755-761

Sissener T. R., Squires E. L. and Clay C. M. (1996) Differential suppression of endometrial prostaglandin F2alpha by the equine conceptus. Theriogenology 45, 541-546

Spencer T. E. and Bazer F. W. (1996) Ovine interferon tau suppresses transcription of the estrogen receptor and oxytocin receptor genes in the ovine endometrium. Endocrinology 137, 1144-1147

Stabenfeldt G. H., Hughes J. P., Evans J. W. and Neely D. P. (1974) Spontaneous prolongation of luteal activity in the mare. Equine Vet. J. 6, 158-163

Starbuck G. R., Stout T. A. E., Lamming G. E. and Allen W. R. (1998) Endometrial oxytocin receptor and uterine prostaglandin secretion in mares during the oestrous cycle and early pregnancy. J. Reprod. Fertil. 113, 173-179

Stevenson K. R., Parkinson T. J. and Wathes D. C. (1991) Measurement of oxytocin concentrations in plasma and ovarian extracts during the estrous cycle of mares. J. Reprod. Fertil. 93, 437-441

Stout T. A. E. and Allen W. R. (2001) Role of prostaglandins in intrauterine migration of the equine conceptus. Reproduction 121, $771-775$

Stout T. A. E. and Allen W. R. (2002) Prostaglandin E2 and F2 $\alpha$ production by equine conceptuses and concentrations in conceptus fluids and uterine flushings recovered from early pregnant and dioestrous mares. Reproduction 123, 261-268

Stout T. A. E., Lamming G. E. and Allen W. R. (1999) Oxytocin administration prolongs luteal function in cyclic mares. J. Reprod. Fertil. 116, 315-320

Vanderwall D. K., Rasmussen D. M. and Woods G. L. (2007) Effect of repeated administration of oxytocin during diestrus on duration of function of corpora lutea in mares. J. Am. Vet. Med. Assoc. 231, 1864-1867

Vanderwall D. K., Silvia W. J. and Fitzgerald B. P. (1998) Concentrations of oxytocin in the intercavernous sinus of mares during luteolysis: temporal relationship with concentrations of 13,14-dihydro-15-keto-prostaglandin F2 $\alpha$. J. Reprod. Fertil. 1 12, 337-346

van Niekerk C. H. and Gerneke W. H. (1966) Persistence and parthenogenetic cleavage of tubal ova in the mare. Onderstepoort J. Vet. Res. 33, 195-232

Vernon M. W., Strauss S., Simonelli M., Zavy M. T. and Sharp D. C. (1979) Specific PGF-2 $\alpha$ by the corpus luteum of the pregnant and non-pregnant mare. J. Reprod. Fertil., Suppl. 27, 421-429

Vernon M. W., Zavy M. T., Asquith R. L. and Sharp D. C. (1981) Prostaglandin $F 2 \alpha$ in the equine endometrium: steroid modulation and production capacities during the estrous cycle and early pregnancy. Biol. Reprod. 25, 581-589

Walters K. W., Roser J. F. and Anderson G. B. (2001) Maternal-conceptus signaling during early pregnancy in mares: oestrogen and insulin-like growth factor I. J. Reprod. Fertil. 121, 331-338

Watson E. D. (1991) Do mares possess an intracellular endometrial inhibitor of prostaglandin synthesis during early pregnancy? Theriogenology 36, 67-71

Wilsher S. and Allen W. R. (2010) Intrauterine administration of plant oils inhibits luteolysis in the mare. Anim. Reprod. Sci. 121S, S58-59

Zavy M. T., Bazer F. W., Sharp D. C., Frank M. and Thatcher W. W. (1978) Uterine luminal prostaglandin F in cycling mares. Prostaglandins 16, 643-650.

Zavy M. T., Vernon M. W., Asquith R. L., Bazer F. W. and Sharp D. C. (1984) Effect of exogenous gonadal steroids and pregnancy on uterine luminal prostaglandin $\mathrm{F}$ in mares. Prostaglandins 27, 31 1-320

Ziecik A. J. (2002) Old, new and the newest concepts of inhibition of luteolysis during early pregnancy in pig. Dom. Anim. Endocrinol. 23, 265-275

Prof. Terttu Katila

University of Helsinki, Faculty of Veterinary Medicine

Department of Production Animal Medicine

Paroninkuja 20, 04920 Saarentaus, Finland

terttu.katila@helsinki.fi 